\title{
THE USE OF LONG ACTING PENICILLINS FOR FINGER INFECTIONS
}

\author{
By V. Parsons, B.M., B.CH. \\ Lately Senior Casualty Officer, King's College Hospital \\ and J. Evans, M.Sc. \\ Research Assistant, Department of Bacteriology, King's College Hospital
}

The aim of this trial, involving 467 patients, was to compare the effectiveness of single injections of a slowly absorbed penicillin with that of a fouror five-day course of daily injections of procainebenzyl penicillin.

It was hoped to answer the following questions:

I. Is one injection as effective as a daily series in assisting the complete healing of finger infections?

2. Does the use of a single injection save outpatient attendances?

3. Is the incidence of reactions higher, more serious or prolonged with the use of slowly released penicillins?

4. Are significant therapeutic blood levels of penicillin maintained in active ambulant patients for a sufficient length of time?

5. Is there any evidence of more frequent emergence of resistant strains of bacteria after the use of slowly released penicillin?

\section{Planning of the Trial}

Patients with finger infections requiring penicillin were allocated, without regard to the type of infection or its severity, to one of three treatment groups according to the day on which they presented.

\section{Group $A$}

Patients first seen in the beginning of the week received a single injection of $3.5 \mathrm{ml}$. containing 600,000 units of benzathine penicillin, 300,000 units of procaine benzyl penicillin and 300,000 units of potassium benzyl penicillin. This preparation is referred to as 'benzathine.' There were I6r patients in this group. (Benzathine penicillin is the $\mathrm{NN}$-dibenzylethylenediamine salt of penicillin.)

\section{Group B}

Patients who were seen in the second part of the week received a single injection of $2.5 \mathrm{ml}$. containing 500,000 units of benethamine penicillin and 300,000 units of procaine benzyl penicillin. This preparation is referred to as 'benethamine.' There were 145 patients in this group. (Benethamine penicillin is the $\mathrm{N}$-benzyl- $\beta$-phenylethylamine salt.)

\section{Group C}

Patients presenting during the weekend were given a four- or five-day course of daily injections of 600,000 units of procaine benzyl penicillin, referred to as 'procaine.' These injections were given deep into the buttock, and never into the arm. The ideal aimed at was to leave small deposits in layers in the muscle. There were 161 patients in this group.

Enquiries were made before treatment as to the length of disability and the history of previous penicillin injections; less than I per cent. of patients were excluded from the above groups because of previous reactions.

The indications for penicillin were:

(a) To prevent spread of infection already present past the interphalangeal joint or manifesting itself as lymphangitis.

(b) To enable incision to be carried out earlier through inflamed and oedematous tissues.

(c) To achieve earlier resolution of pain and suppuration.

The types of infection were classified after Pilcher (1948) and Bailey (1952). For the purpose of this trial four clinical categories were selected; where there was a multiple type of infection the case was included under the most serious type, the majority being pulp infections with spread to include the nail or eponychium. There were no cases of osteomyelitis. Primary infections of the hand and tendon sheaths were excluded.

There were no great differences in the percentage incidence of each type of infection in the three penicillin groups (see Table I), save for a 
TABLE I

Healing Time of Different Clinical Types of Infection (All cases of infection by penicillin-resistant organisms have been excluded)

\begin{tabular}{|c|c|c|c|c|c|c|c|c|c|c|c|c|}
\hline \multirow{3}{*}{ Type of Infection } & \multicolumn{4}{|c|}{ Group A (Benzathine) } & \multicolumn{4}{|c|}{ Group B (Benethamine) } & \multicolumn{4}{|c|}{ Group C (Procaine) } \\
\hline & \multicolumn{3}{|c|}{ Days taken to heal } & \multirow{2}{*}{$\begin{array}{c}\text { Total } \\
\text { (and \%) } \\
\text { of each } \\
\text { type }\end{array}$} & \multicolumn{3}{|c|}{ Days taken to heal } & \multirow{2}{*}{$\begin{array}{c}\text { Total } \\
\text { (and } \% \text { ) } \\
\text { of each } \\
\text { type }\end{array}$} & \multicolumn{3}{|c|}{ Days taken to heal } & \multirow{2}{*}{$\begin{array}{c}\text { Total } \\
\text { (and \%) } \\
\text { of each } \\
\text { type }\end{array}$} \\
\hline & $1-5$ & -10 & $0+$ & & $1-5$ & $6-10$ & rot & & $1-5$ & $6-10$ & rot & \\
\hline $\begin{array}{l}\text { Paranychia } \\
\text { Subcutaneous.. } \\
\text { Distal pulp space } \\
\text { Apical and sub- } \\
\text { ungal }\end{array}$ & $\begin{array}{r}9 \\
11 \\
4 \\
3\end{array}$ & $\begin{array}{r}21 \\
23 \\
14 \\
6\end{array}$ & $\begin{array}{l}26 \\
10 \\
13 \\
6\end{array}$ & $\begin{array}{l}56(38 \%) \\
44(30 \%) \\
31(21 \%) \\
15(11 \%)\end{array}$ & $\begin{array}{r}6 \\
11 \\
3 \\
4\end{array}$ & $\begin{array}{r}17 \\
13 \\
\times 4 \\
5\end{array}$ & $\begin{array}{l}25 \\
13 \\
17 \\
4\end{array}$ & $\begin{array}{l}48(36 \%) \\
37(28 \%) \\
34(26 \%) \\
13(10 \%)\end{array}$ & $\begin{array}{l}9 \\
5 \\
7\end{array}$ & $\begin{array}{r}13 \\
12 \\
7 \\
6\end{array}$ & $\begin{array}{l}19 \\
11 \\
24 \\
9\end{array}$ & $\begin{array}{l}41(32 \%) \\
38(28 \%) \\
38(28 \%) \\
16(12 \%)\end{array}$ \\
\hline Tc & $(19 \%)$ & $\begin{array}{c}64 \\
(44 \%)\end{array}$ & $\begin{array}{c}53 \\
(37 \%)\end{array}$ & 146 & $\begin{array}{c}24 \\
(18 \%)\end{array}$ & $\begin{array}{c}49 \\
(37 \%)\end{array}$ & $\begin{array}{c}59 \\
(45 \%)\end{array}$ & 132 & $\begin{array}{c}22 \\
(17 \%)\end{array}$ & $\begin{array}{c}38 \\
(28 \%)\end{array}$ & $\begin{array}{c}63 \\
(55 \%)\end{array}$ & 13 \\
\hline
\end{tabular}

slight tendency for the more severe infections to weight the procaine series. Of all patients, 76 per cent. required incision; this was usually performed under local analgesic, as described by Holmes and Graff (1953). A swab was taken for bacteriological investigation at operation and, if pus persisted, at weekly intervals thereafter. A number of the more chronic infections received radiant heat and physiotherapy. Blood was obtained from 125 patients at intervals varying from 12 to 96 hours after the injection of penicillin for estimation of penicillin concentration.

\section{Blood Penicillin Investigations Method of Assay}

Assays were performed on serum obtained by venepuncture. The technique was a modification of that recommended by the Food and Drug Administration Antibiotic Laboratory, Washington, D.C. (1947), with sarcina lutea, strain C.P.I. IOOI, as the test organism. Three plates were used for every titration, each plate containing two dilutions of serum (initially neat and $I$ in 2 ) and two standards 0.05 and 0.1 unit penicillin $/ \mathrm{ml}$. in phosphate buffer $\mathrm{pH}$ 6.8. If the zones of inhibition of the serum dilutions were larger than those of the standards, the sera were retested at dilutions which gave inhibitions zones of the same order as the standards. Since two dilutions of standard and unknown were used, the penicillin content of the serum could be calculated from the diameters of the zones of inhibition by a method similar to that described by Gaddum (1953).

\section{Results}

The penicillin content of 56,54 and 19 sera were assayed at varying intervals after intramuscular injections of benethamine, benzathine and procaine penicillin respectively. No attempt was made to take repeated samples from individual patients; in fact, few were sampled on more than
TABLE 4

Prnicillin Concentration of Serum at Various INTERVALS AFTER A SiNGLB INJECTION OF BENZATHINE OR Benethamine Penicillin

\begin{tabular}{|c|c|c|c|c|c|}
\hline \multirow[b]{2}{*}{ Penicillin Concentration } & \multicolumn{5}{|c|}{ Number of Sera } \\
\hline & $\begin{array}{c}\text { 6-18 } \\
\text { hr. }\end{array}$ & $\begin{array}{l}24 \\
\text { hr. }\end{array}$ & $\begin{array}{l}48 \\
\mathrm{hr} .\end{array}$ & $\begin{array}{l}72 \\
\text { hr. }\end{array}$ & $\begin{array}{l}96 \\
\text { hr. }\end{array}$ \\
\hline $\begin{array}{l}\text { O.I units } / \mathrm{ml} \text {. or higher } \ldots \\
0.03-0.1 \text { units } / \mathrm{ml} \text {. } \\
\text { Less than } 0.03 \text { units } / \mathrm{ml} \text {. }\end{array}$ & - & $\begin{array}{r}25 \\
2 \\
3\end{array}$ & $\begin{array}{r}14 \\
10 \\
2\end{array}$ & $\begin{array}{r}6 \\
17 \\
6\end{array}$ & $\begin{array}{l}2 \\
7 \\
1\end{array}$ \\
\hline Total & 13 & 30 & 26 & 29 & 10 \\
\hline
\end{tabular}

one occasion. The results (Table 4 ) show that the sera of 24 out of 26 patients contained more than 0.03 unit of penicillin 48 hours after one or other of the long-acting penicillins; the serum of 23 of 28 patients sampled at 72 hours was also above this figure. $0.03 \mathrm{unit} / \mathrm{ml}$. is commonly regarded as the minimal inhibitory penicillin concentration; there is, however, general agreement that this is below the optimal therapeuticlevel. This obviously varies with the infecting organisms, but for staphylococci and streptococci is probably in the region of 0.1 unit $/ \mathrm{ml}$. (Eagle, Fleishman and Levy, 1953).

Individuals vary greatly in their speed of absorption, excretion and, probably, metabolism of penicillin; the scatter diagram of blood concentration against time shows for each preparation how great this variation is and emphasizes the difficulty of assessing with a relatively small number of estimations the merits of two substances as closely similar as the benzathine and benethamine preparations used in this investigation. There is, however, a trend suggesting that the more rapidly absorbed benethamine gives higher levels than the benzathine penicillin at the doses given, the average values at 24 hours being 0.21 and 0.15 , at 48 hours 0.12 and 0.09 and at 72 hours 0.06 


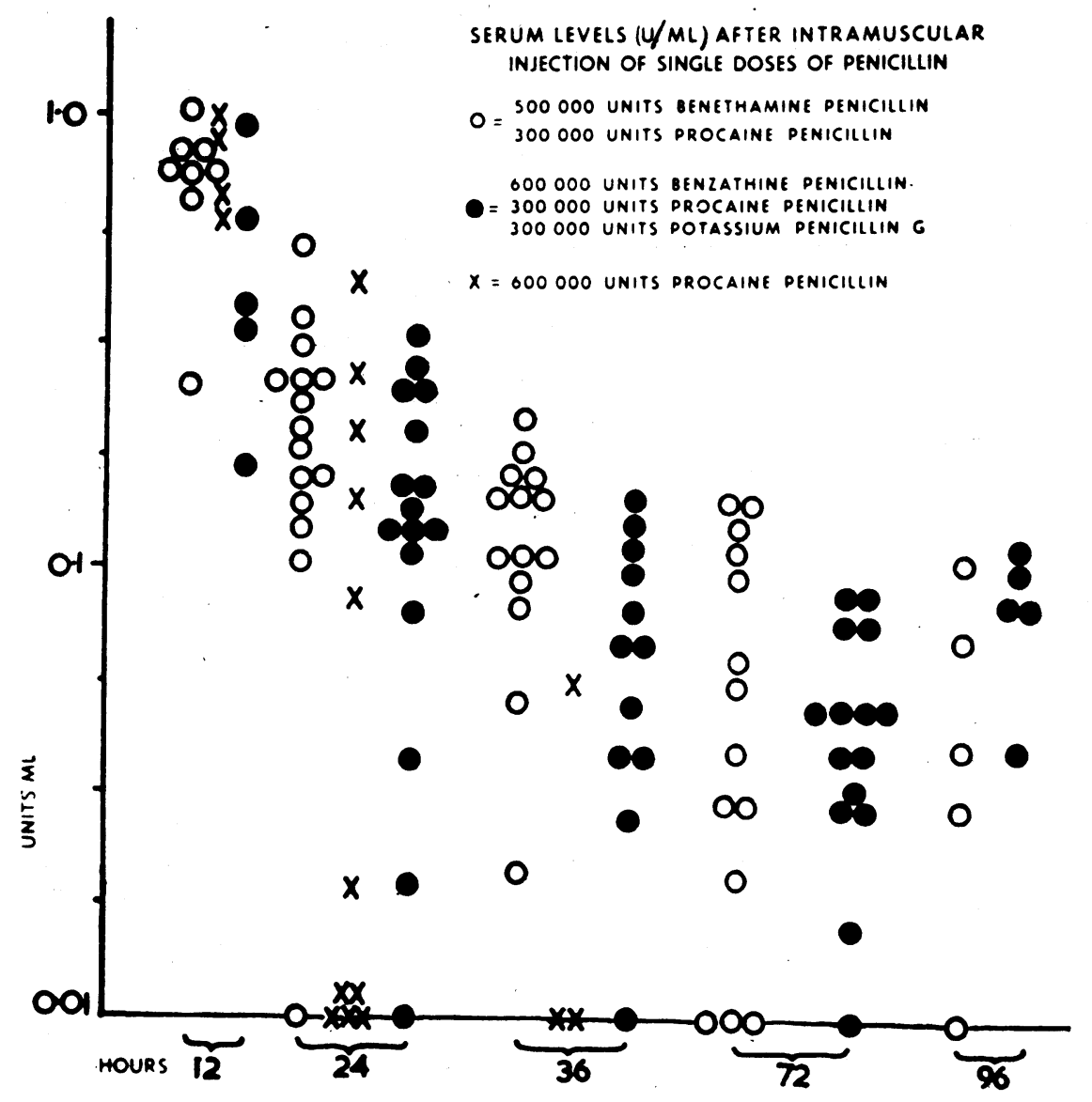

and 0.06 unit $/ \mathrm{ml}$. respectively. Very few sera were examined at longer intervals; at 96 hours, however, the trend is reversed, as would be expected from the findings of Fletcher and Knappett (1953), who showed that penicillin may be detectable, though often intermittently and in low concentration, in the blood for at least 17 days after a single injection of benzathine penicillin.

\section{Assessment of Clinical Results}

Patients were seen at regular intervals for injection or dressing, the latter being disturbed as little as possible. Healing was judged complete when there was full epithelialization, no obvious local swelling or tenderness, and full movement had returned. Patients with infections caused by penicillin-resistant organisms were treated according to their severity with either oral tetracycline hydrochloride (I g. daily for four days) or with local 5 per cent. chloramphenicol in propylene glycol (Lowden, I953). Second courses of penicillin were not given, as suppuration continuing after seven to Io days was usually caused by bacteria resistant to penicillin.

Subjective symptoms referable to the penicillin injections were not considered. Objective findings, such as induration at the site of injections, fever, localized or generalized urticaria or eczema, were recorded and occasionally appeared after the patient had been discharged.

\section{Findings}

Effect on Healing Time

No appreciable difference in the healing time was found between the members of the groups receiving one injection of long-acting penicillin and Group C, who received daily injections. The data in Table I were calculated after the exclusion of infections with penicillin-resistant staphylococci; this reduced the number by 56 to 4 II. It must be emphasized that many infections respond well to incision without penicillin and that, with the numbers reported here, probably only gross differences in the response of the groups would be 
TABle 2

Number of Out-Patient Attendances Before Healing In Each Treatment Group

\begin{tabular}{|c|c|c|c|}
\hline \multirow{2}{*}{$\begin{array}{c}\text { Number } \\
\text { of visits } \\
\text { to } \\
\text { Hospital }\end{array}$} & \multicolumn{3}{|c|}{ Number of Infections Healed } \\
\hline & $\begin{array}{r}\text { Gr } \\
\text { (Ben } \\
(146\end{array}$ & $\begin{array}{r}\text { Gro } \\
\text { (Benet } \\
\text { (132 p }\end{array}$ & $\begin{array}{r}\mathrm{G} \\
(\mathrm{F} \\
(\mathbf{1} 33\end{array}$ \\
\hline $\begin{array}{l}2 \text { or less } \\
4 \text { ", ", } \\
6 \text { ", ", } \\
8 \text { ", ", } \\
\text { 10 ", ", }\end{array}$ & $\begin{array}{r}14(10 \%) \\
62(42 \%) \\
109(74 \%) \\
125(85 \%) \\
133(95 \%)\end{array}$ & $\begin{array}{r}\text { I I }(8 \%) \\
53(40 \%) \\
88(67 \%) \\
\text { I I } 5(87 \%) \\
\text { I25 (95\%) }\end{array}$ & $\begin{array}{r}6(5 \\
30(22 \\
65(49 \\
95(72 \\
113(85\end{array}$ \\
\hline
\end{tabular}

detected. The time taken to heal was calculated from the first day of the penicillin injections, most patients presenting within two days of their first symptoms. Our experience resembled that of Lowden (1953), in that delay in seeking treatment bore no relation to the extent of the lesion or the healing time.

\section{Effect on Attendances}

It is evident from Table 2 that the use of singledose penicillins cuts down the number of hospital attendances; 75 per cent. of the infections of Groups A and B were discharged cured after six or less attendances, as compared with only 49 per cent. of Group C. Only i 5 per cent. of Groups $A$ and $B$ had to attend more than eight times; the same percentage in Group $\mathrm{C}$ had to attend more than ro times.

The use of a single injection of long-acting penicillin in the eight months of this trial resulted in a saving of over 1,000 injections. About 2,000 patient hours were saved for no extra cost.

\section{Penicillin Reactions}

Pain lasting up to 24 hours was fairly common after both of the slowly absorbed preparations, being most marked after benzathine. More severe reactions requiring further treatment occurred in ro of 467 patients; eight of these followed the use of benzathine penicillin. The reactions, seven of which commenced eight days or more after the injection, were of two kinds:

(a) An area of deep brawny induration appeared, extending over $10 \mathrm{~cm}$. in diameter and taking about four days to subside. None of these suppurated.

(b) A generalized massive urticaria often persisting for over a week and requiring intensive treatment with anti-histamines and/or the more effective intravenous calcium gluconate. Details are shown in Table 3 ; reactions were not more common in those who had had penicillin previously (34 per cent. of all patients).

\section{Bacteriological Investigations}

The incidence of penicillin-resistant staphylococci at first sampling was 26 per cent., a slight increase on that recorded three years ago in this hospital (Holmes and Graff, I953); evidence that in the casualty department the problem of penicillin resistance is still very different from that of other hospital departments. Swabs taken from 25 patients on further occasions: in no instance were penicillin-resistant strains found in infections initially sensitive.

\section{Discussion}

In the early stages of finger infection the decision to give penicillin is not always easily made, as it is difficult to predict with accuracy those infections which will give rise to pain or delayed healing. It would, therefore, appear unavoidable that penicillin should be given in many cases where resolution would occur satisfactorily without chemotherapy. Under such circumstances a treat-

TABLE 3

Penicillin Reactions

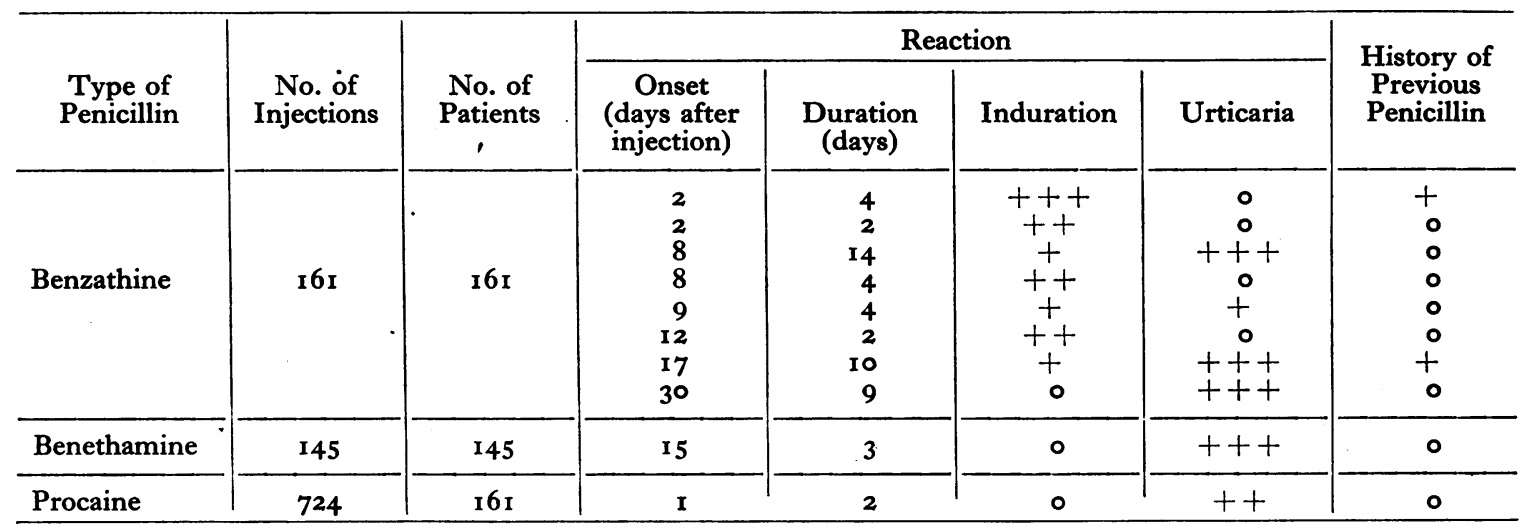


ment involving one injection has obvious advantages both-for convenience of the patient and for administrative reasons. A single large dose $(5 \mathrm{ml}$.) of procaine penicillin has been advocated by Cohen (r953). The more slowly absorbed penicillins, benethamine and benzathine, offer a means of obtaining with smaller doses the prolonged serum penicillin levels obtainable from procaine preparations and a satisfactory trial of benethamine has recently been reported by Williams, Meynell and Watson (1956) in a surgical department and by Wheatley (1956) in general practice. Against this saving in the number of injections must be placed the risks of side-effects. These are mainly of two types, urticarial and inflammatory, representing processes of hypersensitivity and of foreign body reaction respectively. Earlier reports (Nelson, Talbot and Binns, I954) have suggested that injections of large doses of benethamine penicillin are followed by an appreciable risk of reactions of the latter type. This risk, however, appears to be much reduced by the combination of procaine penicillin with benethamine penicillin; thus no significant local reactions were observed after 145 injections of this preparation to our patients. Similarly, no reactions of this type were found after 724 injections of procaine penicillin. In contrast, four of the $\mathrm{r} 6 \mathrm{r}$ patients suffered from moderate to severe amount of pain and induration at the site of injection of the benzathine penicillin preparation, which also contained procaine penicillin.

The urticarial reactions may be of two kinds: immediate ones occurring in patients already sensitized to penicillin-two cases of this type of reaction were observed-and late ones, where the process is probably analogous to serum sickness and previous sensitization has not necessarily occurred. Four reactions of this type were observed, three after the benzathine and one after the benethamine preparation. None of these patients had previously received penicillin. The numbers of these sensitization reactions are too small to warrant a firm conclusion that the risk of sensitization is greater after the more slowly absorbed penicillins than the more rapidly absorbed ones, but, on theoretical grounds, one would expect the risk of the delayed reaction to be greater. Taken as a whole, however, the reactions observed after these long-acting penicillins were relatively mild and their incidence low, considerably less than those described by Grin and Gurthe (1954); and though the risk of reaction appeared to be appreciably greater than that from procaine penicillin, it is, in our opinion, insufficient to outweigh the advantage of a single injection.

\section{Summary}

Four hundred and sixty-seven patients with finger infection were allocated to three treatment groups and received either a course of procaine penicillin or a single injection of a benzathine or benethamine penicillin preparation.

No significant difference was found in the healing time of the lesions of patients in three treatment groups, but the number of out-patient attendances was considerably reduced in both groups receiving the long-acting preparations. The penicillin concentration of the serum of 127 patients was assayed at various intervals after the injection of penicillin. The results emphasized the considerable variation in the serum level that is found after slowly absorbed penicillin preparations, but the sera of over 90 per cent. of those receiving benethamine and benzathine preparations contained more than .03 unit penicillin $/ \mathrm{ml}$. and over 50 per cent. more than 0.1 units $/ \mathrm{ml}$. 48 hours after injection and the majority contained detectable amounts of penicillin after 96 hours. There has been no evidence for the emergence of resistant strains in these local infections. It is our policy to continue with longacting penicillins in the treatment of these infections.

\section{Acknowledgments}

We wish to thank Mr. E. Grainger Muir, Consultant Surgeon to the Casualty Department, for his interest and permission to submit these results, Dr. A. C. Cunliffe for his supervision and advice at all stages and to the eight casualty officers who were on duty in the finger clinic at different times over this period. We are most grateful to Sister Doris and her staff for their able co-operation, to Dr. E. Browne for investigations and to Mr. David Benon for help in collating the results.

The benzathine used in this penicillin trial was generously provided by Messrs. Wyeth as 'Penidural ' and the benethamine penicillin by Messrs. Glaxo Ltd. as an experimental preparation, 'Benapen' (Group B above); this has since been superseded by a preparation, ' Triplopen,' which contains benethamine penicillin 500,000 units, procaine penicillin 250,000 units and sodium benzyl penicillin 500,000 units in each 2-ml. dose.

\section{BIBLIOGRAPHY}

BAILEY, D. (1952), Lancet, i, 167.

COHEN, R. I. (1953) Ibid., i, 168 .

EAGLE, H., FLEISHMAN, R., and LEVY, M. (1953), New Engl. F. Med., 248, 481 .

FLETCHER, A. P., and KNAPPETT, C. R. (1953), Brit. med. $\mathcal{F}$, i, 188.

FOOD AND DRUG ADMINISTRATION, Official Method, Federal Register, April 4, 1947.

GADDUM, J. H. (1953), Y. Pharmacol., 5, 345

GRIN, E. I., and GURTHE, T. (1954), Lancet, i, 832.

HOLMES, P. E. B., and GRAFF, D. J. C. (1953), Brit. med. $\mathcal{F}$., i, 255 .

LOWDEN, T. G. (1953), Lancet, 1, 118.

NELSON, TALBOT and BINNS (1954), Brit. med. F., ii, 339.

PILCHER, R. S., et al. (1948), Lancet, i, 777.

WHEATLEY, D.' (1956), Practitioner, 176, 427.

WILLIAMS, J. A., MEYNELL, M. J., and WATSON, A. B. (1956), Brit. med. Э., i, 716. 